\title{
THE INFLUENCE OF FAMILY SUPPORT, SOCIAL CAPITAL, SELF EFFICACY, EDUCATION, EMPLOYMENT, INCOME, AND RESIDENTIAL STATUS ON THE QUALITY OF LIFE AMONG THE ELDERLY IN SALATIGA, CENTRAL JAVA
}

\author{
Kadarwati' $^{1)}$, RB Soemanto²), Bhisma Murti ${ }^{1,2)}$ \\ 1)Masters Program in Public Health, Sebelas Maret University \\ 2)Faculty of Social and Political Sciences, Sebelas Maret University \\ 3)Department of Public Health, Faculty of Medicine, Sebelas Maret University
}

\begin{abstract}
Background: Lengthening life expectancy of population worldwide has led to rapid growth of the elderly population. This change indicates good development progress. However, it also poses quality of life concern among the elderly. Since the elderly have limitation in many ways, their quality of life decreases, often requiring self-confidence, family support, as well as community awareness, to improve their quality of life. Quality of life is affected by physical, psychological, social and environmental conditions. This study aimed to determine the effects of self efficacy, education, employment status, income, family support, social capital, and residential status on the quality of life of the elderly.
\end{abstract}

Subjects dan Method: This was an analytic observational study using cross-sectional design. The study was conducted in 6 villages, in Sidorejo subdistrict, Salatiga, Central Java, from March to April 2017. A total sample of 150 elderlies aged between 60 to 74 years old were selected for this study by stratified random sampling. The exogenous variables were education, social capital and residential status. The endogenous variables were family support, self efficacy, employment status, income, and the quality of life. The data were collected by a set of questionnaire and analyzed by path analysis.

Results: The quality of life of the elderly was directly affected by income $(b=0.06 ; \mathrm{SE}=1.16 ; \mathrm{p}=0.005)$, family support $(\mathrm{b}=0.14 ; \mathrm{SE}=0.22 ; \mathrm{p}=0.003)$, and self efficacy $(b=0.79 ; \mathrm{SE}=0.11 ; \mathrm{p}<0.001)$. Family support was affected by residence status $(b=0.54 ; \mathrm{SE}=0.88 ; \mathrm{p}<0,001)$, income $(b=0.21 ; \mathrm{SE}=0.40$; $\mathrm{p}<0.001)$, and social capital $(\mathrm{b}=0.41 ; \mathrm{SE}=0.02 ; \mathrm{p}<0.001)$. Self efficacy was affected by family support $(\mathrm{b}=0.54 ; \mathrm{SE}=0.10 ; \mathrm{p}<0.001)$, and social capital $(\mathrm{b}=0.40 ; \mathrm{SE}=0.04 ; \mathrm{p}<0.001)$. Employment status was affected by education $(b=0.16 ; \mathrm{SE}=0.09 ; \mathrm{p}=0.043)$. Income was influenced by education $(\mathrm{b}=0.71$; $\mathrm{SE}=0.06 ; \mathrm{p}<0.001)$.

Conclusion: The quality of life of the elderly is directly affected by income, family support, and self efficacy. The quality of life is indirectly affected by education, employment status, social capital, and residential status.

Keywords: quality of life, influencing factor, elderly, path analysis

Correspondence: Kadarwati. Masters Program in Public Health, Sebelas Maret University, Jl. Ir. Sutami 36 A, Surakarta, Central Java.

Email: kadarwati297@gmail.com. Mobile: +6285728953956. 